\title{
Age, gender and climate associations with the seroprevalence of Neospora species infection in horses in Jordan
}

\author{
Idade, sexo e associações climáticas com a soroprevalência da infecção por \\ Neospora em cavalos da Jordânia
}

Marwan Abu-Halaweh ${ }^{10}$; Mahmoud N. Abo-Shehada2*; Raida Khalil ${ }^{1}$

'Department of Biotechnology and Genetic Engineering, Faculty of Scienctable, Philadelphia University, Jerash, Jordan ${ }^{2}$ Faculty of Epidemiology and Population Health, London School of Hygiene and Tropical Medicine, University of London, London, UK

How to cite: Abu-Halaweh M, Abo-Shehada MN, Khalil R. Age, gender and climate associations with the seroprevalence of Neospora species infection in horses in Jordan. Braz J Vet Parasitol 2020; 29(2): e016019. https://doi.org/10.1590/S1984-29612020004

\begin{abstract}
A cross-sectional study was carried out on a sample of 379 horses to determine the seroprevalence of Neospora spp. in Jordan using the indirect fluorescent antibody test. Five variables, namely locality $(n=10)$, climatic zone $(n=4)$, age group $(n=3)$, gender, and breed were tested as risk factors for Neospora-immunoglobulin (Ig)G seropositivity at four cutoff titers $(1: 50,1: 200,1: 400$, and 1:800) using univariate and multivariate logistic regression analyses. A total of 122 (32\%; 95\% Cl: 28, 37) sera samples had anti-Neospora-IgG at a cutoff titer of 1:50. Increased Neospora-IgG seropositivity was found in horses in three localities (Madaba, Zarka, and Petra) and was associated with the following variables: cool temperate climate; age $>14$ years; and female gender. Seropositivity was found among horses from Madaba at all cutoff titers, Zarka at titers $>1: 200$, and Petra at titers $<1: 200$. Cool temperate climate was associated with titers $<1: 400$. Horses aged $>14$ years were found to be associated with seropositivity at titers $\geq 1: 200$. Female gender was associated with high seropositivity at $>1: 800$.
\end{abstract}

Keywords: Neospora spp., horse, seroprevalence, risk factors, climate, Jordan.

\section{Resumo}

Um estudo transversal foi realizado, na Jordânia, em uma amostra de 379 cavalos, para determinar a soroprevalência de Neospora spp., usando-se o teste de anticorpos fluorescentes indiretos. Cinco variáveis: localidade $(n=10)$, zona climática $(n=4)$, grupo etário $(n=3)$, sexo e raça, foram testadas como fatores de risco para soropositividade para Neospora-imunoglobulina (Ig)G, considerando-se quatro pontos de corte (1:50, 1:200, 1:400 e 1:800) por meio de análises de regressão logística univariada e multivariada. Um total de $122(32 \% ; 95 \% \mathrm{Cl}: 28$, 37) amostras de soros apresentaram anti-Neospora-lgG, utilizando-se como ponto de corte o título de 1:50. Cavalos de três localidades apresentaram aumento da soropositividade para Neospora-lgG (Madaba, Zarka e Petra) o que foi associado às seguintes variáveis: clima temperado fresco; idade > 14 anos; e sexo feminino. Os cavalos de Madaba apresentaram soropositividade em todos os títulos utilizados como ponto de corte; os cavalos de Zarka em títulos >1:200; e os cavalos de Petra em títulos <1:200. O clima temperado fresco foi associado aos títulos $<1: 400$. Cavalos com idade $>14$ anos estiveram associados à soropositividade nos títulos $\geq 1: 200$. 0 sexo feminino esteve associado à alta soropositividade nos títulos $>1: 800$.

Palavras-chave: Neospora spp., cavalo, soroprevalência, fatores de risco, clima, Jordânia. 


\section{Introduction}

Neospora is a coccidian parasite of animals. The genus Neospora has two species: N. caninum and N. hughesi. $N$. caninum is a well-known parasite of domestic and wild animals. It was first isolated from canines that suffered from inflammatory lesions of the skeletal muscles and central nervous system (Anderson et al., 1991; Barr et al., 1994; Dubey \& Lindsay, 1996; Dubey et al., 2007; Donahoe et al., 2015; Dubey et al., 1988). N. caninum is an obligate intracellular pathogen that is capable of utilizing a wide range of animals as intermediate hosts (Dubey et al., 2007; Silva \& Machado, 2016). Cattle, sheep, horses, goats, foxes, deer, buffaloes, and camels are its natural intermediate hosts, with cats, mice, rats, gerbils, and monkeys serving as experimental intermediate hosts (Dubey et al., 2007). Dogs have been identified as both intermediate and definitive hosts of this parasite (Dubey et al., 2007). Dogs are likely to become infected through the ingestion of contaminated tissues, including aborted fetuses, dead calves, or placentas of infected animals. In addition to domestic and wild dogs (Mcallister et al., 1998), other Canids including grey wolves (Dubey et al., 2011), coyotes (Gondim et al., 2004), British red foxes (Bartley et al., 2013), and Australian dingoes (King et al., 2010) are hosts that shed oocysts in the feces, which can serve as a major source of infection for other species. Horizontal and vertical transmissions of $N$. caninum have been reported in cattle, goats, and sheep (Dubey et al., 2007; González-Warleta et al., 2018). A direct association between N. caninum with spontaneous abortion was reported in naturally infected cattle, sheep, goats, (González-Warleta et al., 2018; Dubey \& Schares, 2011; Ghalmi et al., 2011) and horses (Anderson et al., 2019; Leon et al., 2012; Portella et al., 2017; Veronesi et al., 2008).

Conversely, N. hughesi is a poorly known parasite with an unknown life cycle, host range, and infection prevalence, and a definitive host has not yet been determined (Hoane et al., 2005). Recently, serological cross-reactivity was found between N. caninum and N. hughesi (Gondim et al., 2009). Many serologic surveys of N. caninum have been performed without considering potential cross-reactions with N. hughesi (Gondim et al., 2009).

Injordan, the seroprevalence for N. caninum wasfound athigh ratesin sheep, goats(Abo-Shehada\&Abu-Halaweh, 2010), and cattle (Talafha \& Al-Majali, 2013). Seroprevalence of N. caninum in horses in other countries of the Middle East were 0.3\% Turkey (Zhou et al., 2017), 10\% Saudi Arabia (Alanazi et al., 2014), to 32\% Iran (Moraveji et al., 2011). This is a cross-sectional study investigates the seroprevalence of Neospora spp. infection among horses in Jordan and the possible association between locality, climatic zone, age, gender, and breed with Neospora spp. seropositivity at four cutoff titers.

\section{Materials and Methods}

\section{Animals and study area}

Horses in Jordan are bred for different purposes, including for agricultural activities, transport, racing, showing, breeding, and tourism, with estimated numbers of 5,250 horses in this region (Anon, 2007). The examined horses originated from the following 10 localities (Governorates): Irbid, Jerash, Zarqa, Mafraq, Ajlon, Jordan River Valley, Balqa, Amman, Madaba, and Petra, within four climatic zones (cool steppe, cool temperate rainy, warm temperate rainy and cool desert) Figure 1. Most horses live in individual pens (holdings) and small herds in stables.

\section{Sample size determination}

The prevalence of Neospora spp. infection among horses in Jordan has not been previously reported. However, a prevalence rate of $11.9 \%$ was reported from neighboring country (Kligler et al., 2007). According to Thrusfield (Thrusfield, 1995), based on an expected prevalence of 12\%, the appropriate number of horses to be examined as part of this investigation is 267 , as a $99 \%$ level of confidence and $5 \%$ absolute precision were required. Representative samples were selected according to the estimated density in each area. A total of 379 samples were collected. The study had at least $80 \%$ power at a $5 \%$ significance level to detect an odds ratio (OR) $\geq 2$ for risk factors present in $50 \%$ of controls, and an OR $\geq 3$ for those present in $20 \%$ of controls.

\section{Horse sampling and data collection}

During the period spanning April-September 2008, the main areas where horses are raised were visited, and at least $10 \%$ of the herd /holding were sampled systematically (i.e., the first one or two horses), and then every tenth animal ( $90 \%$ of holdings) was also sampled. On some occasions (5\%), permission to sample was denied and the next 


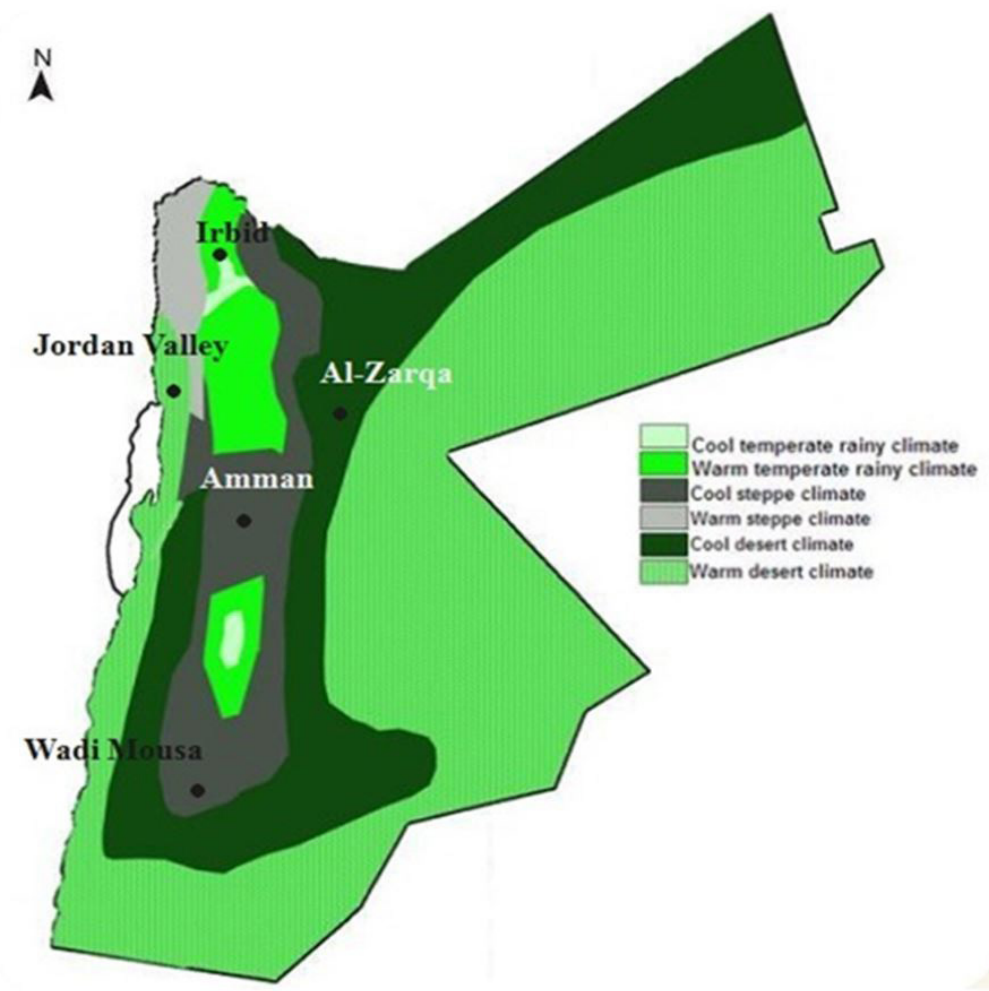

Figure 1. Map of Jordan colors show the different climate regions (Anon, 1984) and the locations were samples have been collected for this study. 1. Warm temperate rainy (Irbid and Jarash (\%21)), 2. Cool steppe (Amman (\%39)), 3. Cool desert (Zarqa (\%38)), 4. Warm desert (Jordan valley), 5. Cool temperate rainy (Wadi Mousa, Petra (\%9)), and 6. Warm steppe (not sampled).

holding was used. Herds and holdings ( $n=268$, ranged from 45 horses to one horse) were sampled once during the study period. Thus, 379 local horses were surveyed for N. caninum. Both male (46\%) and female (45\%) horses were sampled. The majority were of the local breed (93\%) and the rest were thoroughbreds that were imported more than 5 years earlier. The horses ranged from 6 months to 22 years of age (quartiles: Q1, 5; Q2, 8; and Q3, 11.75 years) and were divided into three age groups (<8 years, 45\%; $8-14$ years, 42\%; and >14 years; $13 \%$ ).

Blood samples ( $n=379)$ were collected aseptically from the jugular vein in vacuum tubes. At the time of sampling, information was collected regarding the date of collection, locality, climatic zone, age, gender, and breed.

\section{Serology}

Sera were tested for anti Neospora spp IgG. Slides spotted with whole N. caninum (NC-1 strain) tachyzoites were purchased from VMRD, Inc. (Pullman, WA, USA). Cattle-positive sera and anti-cattle sera labeled with fluorescein were used until positive horse sera were found; then, positive horse sera were used. IgG polyclonal anti-serum anti-horse were produced in goats and conjugated with fluorescein isothiocyanate (VMRD). Tests were carried out as described by the manufacturer and the samples were tested on diluted concentrations of 1:50, 1:100, 1:200, 1:400, and 1:800 in 12-well plates filled with tachyzoites grown in VERO cells and fixed on a Teflon surface. After the reactions ended, glycerol was added, the samples were covered with coverslips, and the reading was carried out immediately using an ultraviolet emission microscope (Olympus CBA, Tokyo, Japan) with 250X magnification and confirmed at $400 \mathrm{X}$ magnification.

\section{Statistical methods}

The data were stored in a database. Statistical analyses were performed using SPSS software version 11 (SPSS Inc., Armonk, NY, USA) and Epi-Info (CDC, Atlanta, GA, USA). A P-value $<0.05$ was considered statistically significant. The $95 \%$ confidence intervals (Cls) were calculated for seroprevalences at four cutoff titers.

A total of five risk factors were tested, including locality [Governorate $(n=10)$ ], climatic zone $(n=4)$, age ( $n=3$ groups), gender, and breed. The dependent variable was Neospora spp. seropositivity status, coded as 0 (negative horse) or 1 (positive horse). This was repeated for positivity at four cutoff titers (1:50, 1:200, 1:400, and 1:800). 
Data were analyzed according to a case-control design, where Neospora spp.-positive and -negative horses were compared in relation to their exposure to potential risk factors (Thrusfield, 1995). Initially, when screening for a significant association between variables in order to identify candidate variables $(P<0.05)$ for the multiple logistic regression model, one risk factor at a time was tested to assess its association with Neospora spp. seropositivity using the chi-squared test and simple logistic regression. For ordered categorical variables, the chi-squared test for trends was employed and Fishers exact test was used when the frequency observed was less than five. ORs with 95\% Cls were calculated. A multivariate analysis was then conducted with all factors that had a $P \leq 0.05$ or an $O R \leq 0.3$ or an $\mathrm{OR} \geq 3.0$ in the univariate analysis. Only those factors that were included in the final models are presented. A $P$-value of $<0.05$ was considered statistically significant.

\section{Results}

The seroprevalence of Neospora spp. among horses was 32\%. Table 1 summarizes the seropositivity of Neospora spp. among horses in Jordan at four cutoff titers.

Table 1. Seropositivity of Neospora spp. infections in horses in Jordan at four cutoff titers ( $n=379)$.

\begin{tabular}{cccc}
\hline Titer & Positive $(\mathbf{N})$ & Seroprevalence $(\%)$ & $95 \% \mathbf{C l}$ \\
\hline $1: 50$ & 122 & 32 & 28,37 \\
$1: 200$ & 74 & 20 & 16,24 \\
$1: 400$ & 37 & 10 & 7,13 \\
$1: 800$ & 30 & 8 & 5,11 \\
\hline
\end{tabular}

In the univariate analysis, localities, climatic zones, and breed were associated with Neospora spp. seropositivity at the four cutoff titers of 1:50, 1:200 1:400, and 1:800 (Tables 2 and 3), in addition to age at cutoff titers of $1: 200$ and 1:800, and gender at a cutoff titer of 1:800.

Table 2. Univariate association between risk factors and Neospora spp. seropositivity at 1:50 and 1:200 cutoff titers among 379 horses in Jordan.

\begin{tabular}{|c|c|c|c|c|c|c|c|}
\hline Variable & Category & Coding & Total $\mathbf{N}$ & $\begin{array}{l}+v e 1: 50 \\
(n=122)\end{array}$ & $P$ & $\begin{array}{c}\text { +ve1:200 } \\
(n=74)\end{array}$ & $P$ \\
\hline \multirow[t]{7}{*}{ Locality } & Irbid & 0 & 17 & $0(0)$ & 0.01 & $0(0)$ & 0.01 \\
\hline & Jerash and Mafraq & 1 & 16 & $10(63)$ & & $6(38)$ & \\
\hline & Zarqa & 2 & 70 & $25(36)$ & & $19(27)$ & \\
\hline & Balqa & 3 & 34 & $10(29)$ & & $4(12)$ & \\
\hline & Amman & 4 & 157 & $33(21)$ & & $23(15)$ & \\
\hline & Madaba & 5 & 35 & $23(66)$ & & $11(31)$ & \\
\hline & Petra & 6 & 50 & $21(42)$ & & $11(22)$ & \\
\hline \multirow[t]{4}{*}{ Climate } & Cool steppe & 0 & 157 & $33(21)$ & 0.01 & $23(15)$ & 0.01 \\
\hline & Cool temperate rainy & 1 & 9 & $8(89)$ & & $5(56)$ & \\
\hline & Warm temperate rainy & 2 & 91 & $35(39)$ & & $16(18)$ & \\
\hline & Cool desert & 3 & 122 & $46(38)$ & & $30(25)$ & \\
\hline \multirow[t]{3}{*}{ Age (Years) } & $<8$ & 0 & 172 & $158(92)$ & 0.20 & $33(19)$ & 0.09 \\
\hline & $8-14$ & 1 & 158 & $44(28)$ & & $26(17)$ & \\
\hline & $>14$ & 2 & 49 & $20(41)$ & & $15(31)$ & \\
\hline
\end{tabular}


Table 2. Continued...

\begin{tabular}{|c|c|c|c|c|c|c|c|}
\hline Variable & Category & Coding & Total N & $\begin{array}{l}\text { +ve 1: } 50 \\
(n=122)\end{array}$ & $P$ & $\begin{array}{c}\text { +ve1:200 } \\
(n=74)\end{array}$ & $P$ \\
\hline \multirow[t]{2}{*}{ Gender } & Male & 0 & 176 & $54(31)$ & 0.32 & $31(18)$ & 0.23 \\
\hline & Female & 1 & 203 & $68(34)$ & & $43(21)$ & \\
\hline \multirow[t]{2}{*}{ Breed } & Thoroughbred & 0 & 28 & $1(4)$ & 0.01 & $1(4)$ & 0.02 \\
\hline & Local & 1 & 351 & $121(35)$ & & $73(21)$ & \\
\hline
\end{tabular}

Table 3. Univariate association between the risk factors and Neospora spp. seropositivity at 1:400 and 1:800 cutoff titers among 379 horses in Jordan.

\begin{tabular}{|c|c|c|c|c|c|c|c|}
\hline Variable & Category & Coding & Total $\mathbf{N}$ & $\begin{array}{c}\text { +ve } 1: 400 \\
(n=37)\end{array}$ & $P$ & $\begin{array}{c}\text { +ve 1:800 } \\
(n=30)\end{array}$ & $P$ \\
\hline \multirow[t]{7}{*}{ Locality } & Irbid & 0 & 17 & $0(0)$ & & $0(0)$ & 0.02 \\
\hline & Jerash and Mafraq & 1 & 16 & $0(0)$ & 0.01 & $0(0)$ & \\
\hline & Zarqa & 2 & 70 & $13(19)$ & & $12(17)$ & \\
\hline & Balqa & 3 & 34 & $0(0)$ & & $0(0)$ & \\
\hline & Amman & 4 & 157 & $12(8)$ & & $8(5)$ & \\
\hline & Madaba & 5 & 35 & $6(17)$ & & $5(14)$ & \\
\hline & Petra & 6 & 50 & $6(12)$ & & $5(10)$ & \\
\hline \multirow[t]{4}{*}{ Climate } & Cool steppe & 0 & 157 & $12(8)$ & 0.01 & $8(5)$ & 0.04 \\
\hline & Cool temperate rainy & 1 & 9 & $0(0)$ & & $0(0)$ & \\
\hline & Warm temperate rainy & 2 & 91 & $6(7)$ & & $5(6)$ & \\
\hline & Cool desert & 3 & 122 & $19(48)$ & & $17(14)$ & \\
\hline \multirow[t]{3}{*}{ Age (Years) } & $<8$ & 0 & 172 & $20(11)$ & 0.20 & $16(9)$ & 0.05 \\
\hline & $8-14$ & 1 & 158 & $9(6)$ & & $7(4)$ & \\
\hline & $>14$ & 2 & 49 & $8(16)$ & & $7(12)$ & \\
\hline \multirow[t]{2}{*}{ Gender } & Male & 0 & 176 & $13(7)$ & 0.32 & $9(5)$ & 0.04 \\
\hline & Female & 1 & 203 & $24(12)$ & & $21(10)$ & \\
\hline \multirow[t]{2}{*}{ Breed } & Thoroughbred & 0 & 28 & $0(0)$ & 0.01 & $0(0)$ & 0.09 \\
\hline & Local & 1 & 351 & $37(11)$ & & $30(9)$ & \\
\hline
\end{tabular}

Following forward selection, three localities (Madaba, Zarqa, and Petra), cool temperate climate, age $>14$ years, and female gender were included in the final models of Neospora spp. seropositivity at cutoff titers of 1:50, 1:200, 1:400, and 1:800 (Tables 4 and 5).

Table 4. Multivariate logistic regression models of the factors associated with Neospora spp. seropositivity at four cutoff titers among 379 horses in Jordan.

\begin{tabular}{cccccc}
\hline Cutoff titer & Variable & Category & $\boldsymbol{P}$ & OR & 95\% Cl \\
\hline $1: 50^{\text {a }}$ & Locality & Petra & 0.009 & 2.3 & $1.2,4.3$ \\
& & Madaba & 0.001 & 6.1 & $2.9,12.8$ \\
& Climate & Cool temperate & 0.001 & 3.1 & $4.0,251$ \\
\hline
\end{tabular}

a Likelihood ratio of chi-squared $\left(\operatorname{LR}_{x} 2\right)=44.4$ on 3 degrees of freedom (d.f.), ${ }^{b R}{ }_{x} 2=20.3$ on 4 d.f., $\operatorname{LR}_{x} 2=10.4$ on 2 d.f., ${ }^{d} L R{ }_{x} 2=20.8$ on 4 d.f. 
Table 4. Continued...

\begin{tabular}{|c|c|c|c|c|c|}
\hline Cutoff titer & Variable & Category & $P$ & OR & $95 \% \mathrm{Cl}$ \\
\hline \multirow[t]{4}{*}{$1: 200^{b}$} & Locality & Madaba & 0.006 & 3.1 & $1.4,6.8$ \\
\hline & & Zarqa & 0.014 & 2.2 & $1.2,4.2$ \\
\hline & Climate & Cool temperate & 0.004 & 6.2 & $1.8,21.8$ \\
\hline & Age & $>14$ years & 0.043 & 2.1 & $1.1,4.2$ \\
\hline \multirow[t]{2}{*}{$1: 400^{c}$} & Locality & Madaba & 0.035 & 2.9 & $1.1,8.0$ \\
\hline & & Zarqa & 0.003 & 3.2 & $1.5,7.0$ \\
\hline \multirow[t]{4}{*}{$1: 800^{d}$} & Locality & Madaba & 0.012 & 4.3 & $1.4,13.5$ \\
\hline & & Zarqa & 0.001 & 4.5 & $1.9,10.7$ \\
\hline & Gender & Female & 0.036 & 2.4 & $1.1,5.6$ \\
\hline & Age & $>14$ years & 0.035 & 2.9 & $1.1,7.6$ \\
\hline
\end{tabular}

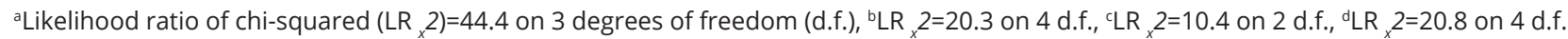

Table 5. Summary of risk factors for Neospora spp. seropositivity at four cutoff titers in Jordan.

\begin{tabular}{ccccc}
\hline \multirow{2}{*}{ Variable } & Category & & & Neospora-IgG titer \\
\cline { 3 - 4 } & & $1: 50$ & $1: 200$ & $1: 400$ \\
Madaba & Zarqa & $*$ & $*$ & $*$ \\
& Petra & $*$ & $*$ & $*$ \\
Climate & Cool temperate & $*$ & $*$ & $*$ \\
Age & $>14$ years & & $*$ & $*$ \\
Gender & Female & & & $*$ \\
\hline
\end{tabular}

* = increasing risk factor

\section{Discussion}

As far as we know, this is the first study to describe the presence of antibodies to Neospora spp. in asymptomatic horses in Jordan. The results demonstrated that horses in Jordan were exposed to Neospora spp. with a high seroprevalence of 32\%, indicating a wide distribution of the infection in Jordan across four climatic zones and all age groups. Seroprevalences of Neospora spp. in horses were reported worldwide (Table 6) and ranged from 0\% in several regions of Brazil and Argentina (Dubey et al., 1999a, b) to 47\% in Parana State, southern Brazil (Locatelli-Dittrich et al., 2006). However, the seroprevalence in horses in Jordan was similar to that of central Wyoming (Dubey et al., 2003) and lower than those reported southern Brazil (47\%) (Locatelli-Dittrich et al., 2006).

Serological cross-reactivity between $N$. caninum and $N$. hughesi antigens has been reported when the indirect fluorescent antibody test (IFAT) and Neospora agglutination test (NAT) were used (Dubey et al., 2001; Figliuolo et al., 2004; Marsh et al., 1996, 1998). Thus, it is difficult to distinguish between these two species using serological tests; as such, molecular techniques are used to identify the Neospora species responsible for the infection (Spencer et al., 2000).

Many factors were reportedly associated with an increased risk for $\mathrm{N}$. caninum seropositivity in cattle, including age and gender (Dyer et al., 2000; Jensen et al., 1999; Rinaldi et al., 2005; Sanderson et al., 2000). The current results showed that seropositivity to Neospora spp. with high titers was associated with horses aged $>14$ years $(\mathrm{OR}=2.9)$. This result is in accordance with previous reports (Kligler et al., 2007; Ciaramella et al., 2004) and may support the notion that vertical transmission in horses might be less efficient than in cattle, which is due to differences in placentation, 
Table 6. Seroprevalences of Neospora spp. in horses in some countries.

\begin{tabular}{|c|c|c|c|c|c|c|}
\hline \multirow{2}{*}{$\begin{array}{c}\text { Region } \\
\text { prevalence } \\
(\%)\end{array}$} & \multirow{2}{*}{ Test } & \multicolumn{2}{|c|}{ Antigen } & \multirow{2}{*}{$\begin{array}{c}\text { No. positive/ } \\
\text { No. } \\
\text { examined }\end{array}$} & \multirow{2}{*}{$\begin{array}{c}\text { Seroprevalence \% } \\
(95 \% \mathrm{CI})\end{array}$} & \multirow{2}{*}{ Reference } \\
\hline & & N. hughesi & N. caninum & & & \\
\hline \multicolumn{7}{|l|}{ USA } \\
\hline $\mathrm{CA}, \mathrm{FL}, \mathrm{MO}, \mathrm{MT}$ & IFAT & $\mathrm{NH}$ & & $23 / 208$ & $11(7,15)$ & (Vardeleon et al., 2001) \\
\hline Alabama & IFAT & $\mathrm{NH}$ & & $59 / 536$ & $11(8,17)$ & (Cheadle et al., 1999) \\
\hline $\begin{array}{l}\text { Central } \\
\text { Wyoming }\end{array}$ & NAT & & NC & $86 / 276$ & $31.1(26,37)$ & (Dubey et al., 2003) \\
\hline \multicolumn{7}{|l|}{ South America } \\
\hline $\begin{array}{l}\text { Brazil, several } \\
\text { states }\end{array}$ & ELISA & $\mathrm{NH}^{*}$ & & $24 / 961$ & $2.5(1.7,3.7)$ & (Hoane et al., 2006) \\
\hline $\begin{array}{l}\text { Brazil, Sao } \\
\quad \text { Paulo }\end{array}$ & IFAT & & NC & $107 / 1106$ & $10.3(8.1,11.6)$ & (Villalobos et al., 2006) \\
\hline $\begin{array}{l}\text { Brazil, Parana } \\
\text { State }\end{array}$ & IFAT & & NC & $17 / 36$ & $47(32.0,63.0)$ & (Locatelli-Dittrich et al., 2006) \\
\hline Brazil & IFAT & NC & NC & $84 / 174$ & $(40.68 .50-55.93)$ & (Cazarotto et al., 2016) \\
\hline Mexico & ELISA & $\mathrm{NH}^{*}$ & & $15 / 495$ & & (Yeargan et al., 2013) \\
\hline Argentina & NAT & & NC & 76 & $0(0.0,4.1)$ & (DUBEY et al., 1999b) \\
\hline \multicolumn{7}{|l|}{ Europe } \\
\hline Sweden & ELISA & $\mathrm{NH}^{* *}$ & & $39 / 414$ & $9(7,12)$ & (Jakubek et al., 2006) \\
\hline France & NAT & & NC & $100 / 434$ & $23(19,27)$ & (Pitel et al., 2001) \\
\hline Italy & IFAT & & NC & $42 / 150$ & $28(21,35)$ & (Ciaramella et al., 2004) \\
\hline \multicolumn{7}{|l|}{ Middle East } \\
\hline Turkey & ELISA & & NC & $7 / 75$ & $9(3,16)$ & (Vural et al., 2006) \\
\hline $\begin{array}{l}\text { Iran (northeast) } \\
\text { Iran (south) }\end{array}$ & N-MAT & & NC-1 & $\begin{array}{l}51 / 150 \\
64 / 200\end{array}$ & $\begin{array}{l}34(26.9,41.9) \\
32(25.9,38.8)\end{array}$ & $\begin{array}{l}\text { (Hosseini et al., 2011) } \\
\text { (Moraveji et al., 2011) }\end{array}$ \\
\hline Saudi Arabia & IFAT & & NC & $29 / 200$ & 10 & $\begin{array}{l}\text { (Alanazi et al., 2014; } \\
\text { Kligler et al., 2007) }\end{array}$ \\
\hline Jordan & IFAT & & NC & $122 / 379$ & $32(28,37)$ & Current study \\
\hline \multicolumn{7}{|l|}{ Far East } \\
\hline South Korea & IFAT & & $\mathrm{NH}$ & $4 / 191$ & $2(0.1,4)$ & (Gupta et al., 2002) \\
\hline $\begin{array}{c}\text { Africa } \\
\text { Nigeria, West } \\
\text { Africa }\end{array}$ & \multicolumn{2}{|r|}{ IFAT } & \multicolumn{2}{|c|}{ NC $10 / 120$} & & (Bartova et al., 2017) \\
\hline
\end{tabular}

*Recombinant NhSAG1; **IH-ISCOM.

as was previously suggested (Pitel et al., 2003). Also, it may indicate horizontal transmission by sporulated oocyst ingestion (Locatelli-Dittrich et al., 2006) and can be taken as evidence of frequent acquired infection.

Likewise, female horses had higher odds ( $\mathrm{OR}=2.9)$ of seropositivity with high titers. Infections in general are known to be associated with stress factors, including parturition and other diseases. Females are at a disadvantage when faced with the stresses of pregnancy and parturition. Such stress is aggravated with local malnutrition practices and the prevalence of other concomitant diseases. Furthermore, higher seroprevalence at high titers in females, 
as reported here, may be similar to that seen in cattle, where the intensity and duration of the specific antibodies during gestation could reflect the intensity of recrudescence of an existing latent infection (Vural et al., 2006) and could be related to the risk of fetal infection (Guy et al., 2001; Stenlund et al., 1999).

Locality was a determining factor in the distribution of Neospora spp. seropositivity. N. caninum infections were evident across all climate ranges available in Jordan (Abo-Shehada \& Abu-Halaweh, 2010), though with different seroprevalences, likely following the presence and relative abundance of the definitive host (i.e., dogs; Table 2 and 3). Furthermore, climate was reported to influence the seroprevalence of N. caninum in farm animals, including cattle (Rinaldi et al., 2005; Schares et al., 2004), sheep, and goats (Abo-Shehada \& Abu-Halaweh, 2010). In this study, the cool temperate climatic zone was found to be an enhancing factor for lower titers <1:400 (cutoff titers of 1: 50 and 1: 200), with ORs of 3.1 and 6.2, respectively. However, such an association was not evident with higher cutoff titers (1:400 and 1:800). In a previous study of sheep and goats in northern Jordan, there was evidence of an association between seropositivity to Neospora spp. and cool temperate climate, with an OR of 0.01 (Abo-Shehada \& Abu-Halaweh, 2010). N. caninum oocysts sporulate in the environment (Vural et al., 2006) and the present results suggest an adverse effect on sporulation in cool, temperate, rainy climates that translate into horses and other animals being exposed to lower numbers of sporulated oocysts.

Overall, this study provided serologic evidence for naturally occurring Neospora spp. infection in Jordanian horses. Neospora spp. infections are widespread in Jordan and pose risks for the development of health problems among horses and other animals in the Middle East. Increased seroprevalences of low and high titers of Neospora spp. were associated with two localities (Madaba and Zarqa), and ages $>14$ years old, while the increased seroprevalence of low titers was associated with the Petra locality and a cool temperate climate. The increased seroprevalence of Neospora spp. was associated with high titers and female gender in horses.

\section{Acknowledgements}

We thank the Deanships of Research, Jordan University of Science and Technology, and Philadelphia University for providing financial support.

\section{References}

Abo-Shehada MN, Abu-Halaweh MM. Flock-level seroprevalence of, and risk factors for, Neospora caninum among sheep and goats in northern Jordan. Prev Vet Med 2010; 93(1): 25-32. http://dx.doi.org/10.1016/j.prevetmed.2009.08.004. PMid:19923025.

Alanazi AD, Said AE, Alhussaini MS, Al-Mohammed HI. Seroepidemiological Studies of Neospora spp. antibodies in Arabian Horses from Riyadh Region, Saudi Arabia. Res J Parasito/ 2014; 9(1): 11-15. http://dx.doi.org10.3923/jp.2014.11.15.

Anderson JA, Alves DA, Cerqueira-Cézar CK, Silva AF, Murata FHA, Norris JK, et al. Histologically, immunohistochemically, ultrastructurally, and molecularly confirmed neosporosis abortion in an aborted equine fetus. Vet Parasitol 2019; 270: 20-24. http://dx.doi.org/10.1016/j.vetpar.2019.04.009. PMid:31213237.

Anderson ML, Blanchard PC, Barr BC, Dubey JP, Hoffman RL, Conrad PA. Neospora-like protozoan infection as a major cause of abortion in California dairy cattle. J Am Vet Med Assoc 1991; 198(2): 241-244. PMid:2004983.

Anon. National Atlas of Jordan: Climate and agroclimatology. Amman: Jordan National Geographic Centre; 1984.

Anon. The annual report. Jordan: Ministry of Agricultuer; 2007.

Barr BC, Conrad PA, Sverlow KW, Tarantal AF, Hendrickx AG. Experimental fetal and transplacental Neospora infection in the nonhuman primate. Lab Invest 1994; 71(2): 236-242. PMid:8078303.

Bartley PM, Wright SE, Zimmer IA, Roy S, Kitchener AC, Meredith A, et al. Detection of Neospora caninum in wild carnivorans in Great Britain. Vet Parasitol 2013; 192(1-3): 279-283. http://dx.doi.org/10.1016/j.vetpar.2012.10.001. PMid:23102760.

Bártová E, Sedlak K, Kobedova K, Budikova M, Joel Atuman Y, Kamani J. Seroprevalence and risk factors of Neospora spp. and Toxoplasma gondii infections among horses and donkeys in Nigeria, West Africa. Acta Parasitol 2017; 62(3): 606-609. http://dx.doi. org/10.1515/ap-2017-0073. PMid:28682771.

Cazarotto CJ, Balzan A, Grosskopf RK, Boito JP, Portella LP, Vogel FF, et al. Horses seropositive for Toxoplasma gondii, Sarcocystis spp. and Neospora spp.: possible risk factors for infection in Brazil. Microb Pathog 2016; 99: 30-35. http://dx.doi.org/10.1016/j. micpath.2016.07.016. PMid:27475033. 
Cheadle MA, Lindsay DS, Rowe S, Dykstra CC, Williams MA, Spencer JA, et al. Prevalence of antibodies to Neospora sp. in horses from Alabama and characterisation of an isolate recovered from a naturally infected horse. Int J Parasitol 1999; 29(10): 15371543. http://dx.doi.org/10.1016/S0020-7519(99)00140-X. PMid:10608440.

Ciaramella P, Corona M, Cortese L, Piantedosi D, Santoro D, Di Loria A, et al. Seroprevalence of Neospora spp. in asymptomatic horses in Italy. Vet Parasitol 2004; 123(1-2): 11-15. http://dx.doi.org/10.1016/j.vetpar.2004.05.022. PMid:15265566.

Donahoe SL, Lindsay SA, Krockenberger M, Phalen D, Slapeta J. A review of neosporosis and pathologic findings of Neospora caninum infection in wildlife. Int J Parasitol Parasites Wildl 2015; 4(2): 216-238. http://dx.doi.org/10.1016/j.ijppaw.2015.04.002. PMid:25973393.

Dubey JP, Carpenter JL, Speer CA, Topper MJ, Uggla A. Newly recognized fatal protozoan disease of dogs. J Am Vet Med Assoc 1988; 192(9): 1269-1285. PMid:3391851.

Dubey JP, Jenkins MC, Rajendran C, Miska K, Ferreira LR, Martins J, et al. Gray wolf (Canis lupus) is a natural definitive host for Neospora caninum. Vet Parasitol 2011; 181(2-4): 382-387. http://dx.doi.org/10.1016/j.vetpar.2011.05.018. PMid:21640485.

Dubey JP, Kerber CE, Granstrom DE. Serologic prevalence of Sarcocystis neurona, Toxoplasma gondii, and Neospora caninum in horses in Brazil. J Am Vet Med Assoc 1999a; 215(7): 970-972. PMid:10511862.

Dubey JP, Liddell S, Mattson D, Speer CA, Howe DK, Jenkins MC. Characterization of the Oregon isolate of Neospora hughesi from a horse.J Parasito/ 2001; 87(2): 345-353. http://dx.doi.org/10.1645/0022-3395(2001)087[0345:COTOIO]2.0.CO;2. PMid:11318565.

Dubey JP, Lindsay DS. A review of Neospora caninum and neosporosis. Vet Parasito/ 1996; 67(1-2): 1-59. http://dx.doi.org/10.1016/ S0304-4017(96)01035-7. PMid:9011014.

Dubey JP, Mitchell SM, Morrow JK, Rhyan JC, Stewart LM, Granstrom DE, et al. Prevalence of antibodies to Neospora caninum, Sarcocystis neurona, and Toxoplasma gondii in wild horses from central Wyoming. J Parasito/ 2003; 89(4): 716-720. http://dx.doi. org/10.1645/GE-66R. PMid:14533680.

Dubey JP, Schares G, Ortega-Mora LM. Epidemiology and control of neosporosis and Neospora caninum. Clin Microbiol Rev 2007; 20(2): 323-367. http://dx.doi.org/10.1128/CMR.00031-06. PMid:17428888.

Dubey JP, Schares G. Neosporosis in animals: The last five years. Vet Parasito/ 2011; 180(1-2): 90-108. http://dx.doi.org/10.1016/j. vetpar.2011.05.031. PMid:21704458.

Dubey JP, Venturini MC, Venturini L, McKinney J, Pecoraro M. Prevalence of antibodies to Sarcocystis neurona, Toxoplasma gondii and Neospora caninum in horses from Argentina. Vet Parasito/ 1999b; 86(1): 59-62. http://dx.doi.org/10.1016/S0304-4017(99)001272. PMid:10489203.

Dyer RM, Jenkins MC, Kwok OC, Douglas LW, Dubey JP. Serologic survey of Neospora caninum infection in a closed dairy cattle herd in Maryland: risk of serologic reactivity by production groups. Vet Parasito/ 2000; 90(3): 171-181. http://dx.doi.org/10.1016/ S0304-4017(00)00253-3. PMid:10841997.

Figliuolo LP, Kasai N, Ragozo AM, Paula VS, Dias RA, Souza SL, et al. Prevalence of anti-Toxoplasma gondii and anti-Neospora caninum antibodies in ovine from Sao Paulo State, Brazil. Vet Parasitol 2004; 123(3-4): 161-166. http://dx.doi.org/10.1016/j. vetpar.2004.06.006. PMid:15325042.

Ghalmi F, China B, Kaidi R, Losson B. Neospora caninum is associated with abortion in Algerian cattle. J Parasitol 2011; 97(6): 1121-1124. http://dx.doi.org/10.1645/GE-2861.1. PMid:21728878.

Gondim LF, Lindsay DS, McAllister MM. Canine and bovine Neospora caninum control sera examined for cross-reactivity using Neospora caninum and Neospora hughesi indirect fluorescent antibody tests.J Parasito/ 2009; 95(1): 86-88. http://dx.doi.org/10.1645/ GE-1710.1. PMid:18613752.

Gondim LF, McAllister MM, Pitt WC, Zemlicka DE. Coyotes (Canis latrans) are definitive hosts of Neospora caninum. Int J Parasitol 2004; 34(2): 159-161. http://dx.doi.org/10.1016/j.ijpara.2004.01.001. PMid:15037103.

González-Warleta M, Castro-Hermida JA, Calvo C, Pérez V, Gutiérrez-Expósito D, Regidor-Cerrillo J, et al. Endogenous transplacental transmission of Neospora caninum during successive pregnancies across three generations of naturally infected sheep. Vet Res 2018; 49(1): 106. http://dx.doi.org/10.1186/s13567-018-0601-3. PMid:30333061.

Gupta GD, Lakritz J, Kim JH, Kim DY, Kim JK, Marsh AE. Seroprevalence of Neospora, Toxoplasma gondii and Sarcocystis neurona antibodies in horses from Jeju island, South Korea. Vet Parasitol 2002; 106(3): 193-201. http://dx.doi.org/10.1016/S03044017(02)00064-X. PMid:12062508.

Guy CS, Williams DJL, Kelly DF, McGarry JW, Guy F, Bjorkman C, et al. Neospora caninum in persistently infected, pregnant cows: spontaneous transplacental infection is associated with an acute increase in maternal antibody. Vet Rec 2001; 149(15): 443-449. http://dx.doi.org/10.1136/vr.149.15.443. PMid:11688746. 
Hoane JS, Gennari SM, DubeyJP, Ribeiro MG, Borges AS, Yai LE, et al. Prevalence of Sarcocystis neurona and Neospora spp. infection in horses from Brazil based on presence of serum antibodies to parasite surface antigen. Vet Parasitol 2006; 136 (2): $155-159$. http://dx.doi.org/10.1016/j.vetpar.2005.10.023. PMid:16310955.

Hoane JS, Yeargan MR, Stamper S, Saville WJ, Morrow JK, Lindsay DS, et al. Recombinant NhSAG1 ELISA: A sensitive and specific assay for detecting antibodies against Neospora hughesi in equine serum.J Parasito/ 2005; 91(2): 446-452. http://dx.doi.org/10.1645/ GE-395R. PMid:15986623.

Hosseini M, Moraveji M, Tahamtan Y, Rahimian A, Mohammadi G, Namavari M. Seroprevalence of Neospora spp. in Horses in North East of Iran. Iran J Parasitol 2011; 6(2): 64-68. PMid:22347290.

Jakubek EB, Lunden A, Uggla A. Seroprevalences of Toxoplasma gondii and Neospora sp. infections in Swedish horses. Vet Parasitol 2006; 138(3-4): 194-199. http://dx.doi.org/10.1016/j.vetpar.2006.02.002. PMid:16517077.

Jensen AM, Bjorkman C, Kjeldsen AM, Wedderkopp A, Willadsen C, Uggla A, et al. Associations of Neospora caninum seropositivity with gestation number and pregnancy outcome in Danish dairy herds. Prev Vet Med 1999; 40(3-4): 151-163. http://dx.doi. org/10.1016/S0167-5877(99)00048-3. PMid:10423771.

King JS, Šlapeta J, Jenkins DJ, Al-Qassab SE, Ellis JT, Windsor PA. Australian dingoes are definitive hosts of Neospora caninum. Int J Parasitol 2010; 40(8): 945-950. http://dx.doi.org/10.1016/j.ijpara.2010.01.008. PMid:20149793.

Kligler EB, Shkap V, Baneth G, Mildenberg Z, Steinman A. Seroprevalence of Neospora spp. among asymptomatic horses, aborted mares and horses demonstrating neurological signs in Israel. Vet Parasitol 2007; 148(2): 109-113. http://dx.doi.org/10.1016/j. vetpar.2007.06.002. PMid:17614202.

Leon A, Richard E, Fortier C, Laugier C, Fortier G, Pronost S. Molecular detection of Coxiella burnetii and Neospora caninum in equine aborted foetuses and neonates. Prev Vet Med 2012; 104(1-2): 179-183. http://dx.doi.org/10.1016/j.prevetmed.2011.11.001. PMid:22130310.

Locatelli-Dittrich R, Dittrich JR, Richartz RR, Gasino Joineau ME, Antunes J, Pinckney RD, et al. Investigation of Neospora sp. and Toxoplasma gondii antibodies in mares and in precolostral foals from Parana State, Southern Brazil. Vet Parasito/ 2006; 135(3-4): 215-221. http://dx.doi.org/10.1016/j.vetpar.2005.10.010. PMid:16289863.

Marsh AE, Barr BC, Madigan J, Lakritz J, Nordhausen R, Conrad PA. Neosporosis as a cause of equine protozoal myeloencephalitis. J Am Vet Med Assoc 1996; 209(11): 1907-1913. PMid:8944807.

Marsh AE, Barr BC, Packham AE, Conrad PA. Description of a new Neospora species (Protozoa: Apicomplexa: Sarcocystidae). J Parasito/ 1998; 84(5): 983-991. http://dx.doi.org/10.2307/3284632. PMid:9794642.

McAllister MM, Dubey JP, Lindsay DS, Jolley WR, Wills RA, McGuire AM. Dogs are definitive hosts of Neospora caninum. Int J Parasitol 1998; 28(9): 1473-1478. http://dx.doi.org/10.1016/S0020-7519(98)00138-6. PMid:9770635.

Moraveji M, Hosseini MH, Amrabadi O, Rahimian A, Namazi F, Namavari M. Seroprevalence of Neospora spp. in horses in South of Iran. Trop Biomed 2011; 28(3): 514-517. PMid:22433879.

Pitel PH, Pronost S, Romand S, Thulliez P, Fortier G, Ballet JJ. Prevalence of antibodies to Neospora caninum in horses in France. Equine VetJ 2001; 33(2): 205-207. http://dx.doi.org/10.1111/j.2042-3306.2001.tb00602.x. PMid:11266072.

Pitel PH, Romand S, Pronost S, Foucher N, Gargala G, Maillard K, et al. Investigation of Neospora sp. antibodies in aborted mares from Normandy, France. Vet Parasito/ 2003; 118(1-2): 1-6. http://dx.doi.org/10.1016/j.vetpar.2003.10.007. PMid:14651869.

Portella LP, Cadore GC, Sangioni LA, Pellegrini LF, Fighera R, Ramos F, et al. Antibodies against Apicomplexa protozoa and absence sarcocysts in heart tissues from horses in southern Brazil. Rev Bras Parasitol Vet 2017; 26(1): 100-103. http://dx.doi.org/10.1590/ s1984-29612016068. PMid:28327879.

Rinaldi L, Fusco G, Musella V, Veneziano V, Guarino A, Taddei R, et al. Neospora caninum in pastured cattle: determination of climatic, environmental, farm management and individual animal risk factors using remote sensing and geographical information systems. Vet Parasitol 2005; 128(3-4): 219-230. http://dx.doi.org/10.1016/j.vetpar.2004.12.011. PMid:15740859.

Sanderson MW, GayJM, Baszler TV. Neospora caninum seroprevalence and associated risk factors in beef cattle in the northwestern United States. Vet Parasitol 2000; 90(1-2): 15-24. http://dx.doi.org/10.1016/S0304-4017(00)00234-X. PMid:10828508.

Schares G, Barwald A, Staubach C, Ziller M, Kloss D, Schroder R, et al. Potential risk factors for bovine Neospora caninum infection in Germany are not under the control of the farmers. Parasitology 2004; 129(Pt 3): 301-309. http://dx.doi.org/10.1017/ S0031182004005700. PMid:15471005.

Silva RC, Machado GP. Canine neosporosis: perspectives on pathogenesis and management. Vet Med (Auckl) 2016 ; 7: 59-70. http://dx.doi.org/10.2147/VMRR.S76969. PMid:30050838. 
Spencer JA, Witherow AK, Blagburn BL. A random amplified polymorphic DNA polymerase chain reaction technique that differentiates between Neospora species.J Parasito/ 2000; 86(6): 1366-1368. http://dx.doi.org/10.1645/0022-3395(2000)086[1366:AR APDP]2.0.CO;2. PMid:11191920.

Stenlund S, Kindahl H, Magnusson U, Uggla A, Bjorkman C. Serum antibody profile and reproductive performance during two consecutive pregnancies of cows naturally infected with Neospora caninum. Vet Parasitol 1999; 85(4): 227-234. http://dx.doi. org/10.1016/S0304-4017(99)00120-X. PMid:10488725.

Talafha AQ, Al-Majali AM. Prevalence and risk factors associated with Neospora caninum infection in dairy herds in Jordan. Trop Anim Health Prod 2013; 45(2): 479-485. http://dx.doi.org/10.1007/s11250-012-0244-8. PMid:22869339.

Thrusfield M. Veterinary Epidemiology. London: Blackwell Science; 1995.

Vardeleon D, Marsh AE, Thorne JG, Loch W, Young R, Johnson PJ. Prevalence of Neospora hughesi and Sarcocystis neurona antibodies in horses from various geographical locations. Vet Parasitol 2001; 95(2-4): 273-282. http://dx.doi.org/10.1016/S03044017(00)00393-9. PMid:11223207.

Veronesi F, Diaferia M, Mandara MT, Marenzoni ML, Cittadini F, Piergili Fioretti D. Neospora spp. infection associated with equine abortion and/or stillbirth rate. Vet Res Commun 2008;32(S1 Suppl. 1): S223-S226. http://dx.doi.org/10.1007/s11259-008-9155-6. PMid:18696243.

Villalobos EM, Ueno TE, Souza SL, Cunha EM, Hunold Lara MCCS, Gennari SM, et al. Association between the presence of serum antibodies against Neospora spp. and fetal loss in equines. Vet Parasitol 2006; 142(3-4): 372-375. http://dx.doi.org/10.1016/j. vetpar.2006.07.016. PMid:16962708.

Vural G, Aksoy E, Bozkir M, Kuçukayan U, Erturk A. Seroprevalence of Neospora caninum in dairy cattle herds in Central Anatolia, Turkey. Vet Arh 2006; 76(4): 343-349.

Yeargan MR, Alvarado-Esquivel C, Dubey JP, Howe DK. Prevalence of antibodies to Sarcocystis neurona and Neospora hughesi in horses from Mexico. Parasite 2013; 20: 29. http://dx.doi.org/10.1051/parasite/2013029. PMid:24016396.

Zhou M, Cao S, Sevinc F, Sevinc M, Ceylan O, Liu M, et al. Enzyme-linked immunosorbent assays using recombinant TgSAG2 and NcSAG1 to detect Toxoplasma gondii and Neospora caninum-specific antibodies in domestic animals in Turkey.J Vet Med Sci 2017; 78(12): 1877-1881. http://dx.doi.org/10.1292/jvms.16-0234. PMid:27523504. 